\title{
The economic impacts of constructing an ATV bypass route in the Town of Conception Bay South
}

\author{
Krista Perry
}

The development and maintenance of trails that permit the use of off-road vehicles present tremendous opportunities for tourism product development. Newfoundland and Labrador is hoping to capitalize from trail users by building a province-wide trail network using the former Canadian National Railway line. Since the section of the trail through the Town of Conception Bay South is non-motorized, the Town hopes to build an ATV Bypass Route in order to draw all-terrain vehicle (ATV) users and create a continuous trail for them. This paper presents information on the economic impact of the ATV industry and case studies from similar jurisdictions in Canada and the United States to support the argument that ATV tourism is a good investment.

Keywords: economic impact, trail development, tourism, recreation, all terrain vehicles, Newfoundland

\section{Introduction}

Throughout North America, motorized trails are becoming increasingly important and relevant. In a study commissioned by the National Trails Coalition in 2010, consultants determined that there are over $278,000 \mathrm{~km}$ of managed trails throughout Canada, of which motorized use represents $66.4 \%$ of total kilometers (Norman, 2010). The development and maintenance of trails that permit the use of off-road vehicles present tremendous opportunities for tourism product development. In Newfoundland and Labrador approximately 3,600 km of managed trails are designated for snowmobile use, while an additional $1,000 \mathrm{~km}$ are characterised for use by AllTerrain Vehicle (ATV)/Off-Road Vehicle (ORV) (Norman, 2010).

Small rural towns have been able to draw more tourism dollars through the development and establishment of off-road trail parks and networks (Nopper and Balenovich, 2011). Studies indicate that trails of all types have significant economic benefits for the local communities that support them, and there is a strong business case for public investment in trail infrastructure (PricewaterhouseCooper LLP, 2004). Studies of three multi-use, pay-per-use trails undertaken by Englin and Holmes (2005), and Englin, Holmes and Neill (2006) in North Carolina established that consumers were spending between $\$ 25-\$ 1,000$ within the community and on the trail network. Another study found that the travel parties of New Brunswick trail permit holders spent an average of $\$ 1,653$ annually on same-day out-of-town trips. 
Newfoundland and Labrador is hoping to capitalize from trail users by building a province-wide trail network. Leading the effort is the Newfoundland T'Railway Council, a non-profit corporation dedicated to the development of a recreational trail from St. John's to Port aux Basques using the former Canadian National Railway line. Their mandate is to promote multiuse trail development and to preserve abandoned railway lines for future use such as hiking, biking, equestrian, snowmobile, ATV and cross-country ski trails (Newfoundland T'Railway Council, 2014). The Newfoundland T'Railway stretches $883 \mathrm{~km}$ across the island of Newfoundland, with the vast majority designated as mixed use, allowing both non-motorized and motorized use; only $33 \mathrm{~km}$ on the Northeast Avalon Peninsula is designated as non-motorized, more than half of which is within the boundaries of the Town of Conception Bay South.

In order to draw ATV users and create a continuous trail for them, Conception Bay South plans to build an ATV Bypass Route, connecting with the cross-island T'Railway Provincial Park at its western terminus in Holyrood. There has been much discussion regarding both the potential and actual economic impacts of motorized trail usage in communities adjacent to their development. This paper will support that discussion by collecting research on how motorized trails can complement local tourism activities. Much of the research is from the United States, but the underlying elements of motorized trails and their users across Canada and the United States have similarities that make comparisons appropriate.

\section{Background on the Newfoundland T'Railway}

In 1988 the railway line running across the island of Newfoundland was abandoned. Though an important chapter in the province's transportation history had drawn to a close, a new one was about to begin. Over $800 \mathrm{~km}$ of abandoned rail bed between Port aux Basques on the west coast and St. John's on the east coast will be converted to a multi-use, all-season recreational trail. The Newfoundland T'Railway Provincial Park — officially proclaimed as such on July 10, 1997—is being developed by the Newfoundland T'Railway Council in conjunction with the provincial and federal governments, various municipal councils and local service districts, the Trans Canada Trail Foundation, and a number of other economic development organizations (Newfoundland T'Railway Council, 2014).

Development of the T'Railway is being carried out over a number of phases, as funds become available. Much of the initial work involved brush cutting, general clean-up, and clearing ditches of accumulated debris. Upgrading all 130 bridges and trestles was the largest undertaking, lasting 15 years and requiring financing from the Atlantic Canada Opportunities Agency, the Government of Newfoundland and Labrador, and the Trans Canada Trail Foundation (Newfoundland T'Railway Council, 2014). The work involved the installation of new decking and safety railing, improvements to bridge approaches, abutment enhancements, erosion protection, gravel backfilling and the erection of safety and information signs. In total, there are about 3.5 kilometers of bridges along the trail, all of which was upgraded by 2010 
(Newfoundland T'Railway Council, 2014). However, given the expansive distance covered by the T'Railway across the island, the T'Railway Provincial Park will likely always be a work in progress. While technically connected from St. John's to Port aux Basques, there are currently sections that are impassable, including two bridges in need of repair and a relatively short section of trail which needs to be re-established on the province's west coast.

As previously stated, the T'Railway was designated a provincial park under Provincial legislation and thus, future upgrades and maintenance (particularly repairing damage from spring runoff and heavy snowmobile traffic) will be the responsibility of the Province. That being said, certain sections of the T'Railway have been leased from the province by other jurisdictions for further development, control and maintenance. The Town of Conception Bay South is one such jurisdiction since it embarked on the T'Railway Development Project in 2013 and leased the 18 $\mathrm{km}$ section of the rail bed within its municipal boundaries. This effectively turned all responsibility for T'Railway development, maintenance, and liability over to the Town. In order to secure funding for these expenses, the Town sought and was granted an Off-Road Vehicle Prohibitive Order (Provincial Order 114/13) which was implemented along the entire $18 \mathrm{~km}$ route.

Since the T'Railway in Conception Bay South has been designated exclusively for nonmotorized use, a new ATV Bypass Route is being actively pursued to accommodate motorized recreation vehicles in an effort to capitalize on tourism opportunities currently excluded from the T'Railway. Exit surveys obtained by the Province in 2011 (updated in April 2013) found that approximately 3\% of out-of-province visitors participated in some form of All Terrain Vehicle touring (Government of Newfoundland and Labrador, 2013). This, combined with stable provincial ATV sales-approximately 3,000 new units annually since 2007 (Motorcycle \& Moped Industry Council and the Canadian Off-Highway Vehicle Distributors Council, 2013) indicates a ready market for ATV tourism, with significant potential to expand.

\section{Proposed Town of Conception Bay South ATV Bypass Route}

Ideally positioned $25 \mathrm{~km}$ from the City of St. John's, the Town of Conception Bay South has a growing population of approximately 26,000 and a trade area of over 237,000 within a $30 \mathrm{~km}$ radius. The Town of Conception Bay South is perfectly situated to offer a range of amenities to a region that continues to enjoy exponential growth and a booming tourism industry.

The Town completed a Tourism Infrastructure Master Plan in 2002 which identified a number of strategies that might be used to increase visitation to the Town. A strong emphasis was placed on attracting day-trippers from neighboring St. John's (the provincial capital) as well as on product development initiatives that could be undertaken to enhance the Town's capacity to attract and manage tourists. 
In the 14 years since the study, significant pieces of tourism infrastructure have been added which greatly enhance the Town's ability to compete for tourist visitation in the region. Most notably, the Manuels River Hibernia Interpretation Centre, a world-class interpretation and event venue opened in 2013 on the banks of Manuels River and has become a major tourism hub for the Town. It serves as the Town's Visitor Information Centre, and its location affords visitors easy and convenient access to the Manuels River Trail System, as well as the T'Railway.

The T'Railway Development Project is a significant component of the Town's growing tourism inventory. The T'Railway was long identified as having significant tourism potential for its ability to connect with neighbouring municipalities, including the City of St. John's, via an interconnected trail system. As far back as 2007, the Conception Bay South T'Railway Study highlighted the opportunity the T'Railway created to serve as the 'spine' for an integrated system of parks and trails within the Town. Since the T'Railway accommodates bicycles and pedestrians only, and a new ATV Bypass Route was recommended to accommodate motorized recreation vehicles. The Town has a long history with motorized ATV use and the Town of Conception Bay South sees the potential of a product alliance within the region built around the ATV experience. The objective is to maximize the economic development benefits for the Town and the region to provide a unique tourist destination that complements previously completed studies and development plans.

The $26 \mathrm{~km}$ ATV Bypass Route will create an alternative backcountry corridor for ATVs and other motorized recreational vehicles, providing expanded economic development and tourism opportunities for the Region without disturbing non-motorized trail users. It will add direct and indirect economic benefits to the Town and region by linking ATV users to the local business community and providing opportunities for new services and amenities that cater to the off-road motorized vehicle market. These may include ATV and trailer rentals, guided tour packages, as well as parking and storage for machines and trailers whose owners want to travel eastward to the capital city without the hassle of towing a loaded trailer. New jobs may be created via the construction and maintenance of the route, as well as in the tourism sector (accommodations, food service, and retail).

An additional benefit of developing the ATV Bypass Route is the opportunity to capitalize on changing local weather patterns seen in recent years. Warmer winter temperatures and variable snow cover have the potential to extend the ATV riding season by several weeks. A study of ATV riding activities in Haliburton County, ON (Coles, 2011), showed that many people are trading snowmobiles for ATVs as snowfall becomes less frequent and more unpredictable.

The creation of an ATV Bypass Route is in line with the economic development goals of the Town, and supported by growing evidence from other jurisdictions that have derived significant benefits from motorized trail users. The ATV Bypass Route will link the ATV users to the local 
business community while maintaining responsibility to all interests respecting both the environment and the public.

The next two sections will provide information that supports the argument that ATV tourism is a good investment.

\section{ATV/ORV proliferation and economic impact}

In a report commissioned by the Canadian All-Terrain Vehicles Distributors Council (Gunther, 2006), the increasing popularity of ATV/ORV sporting in Newfoundland and Labrador was attributed to rising provincial incomes and the relocation of workforce jobs to Alberta. The report focused on the economic impact of ATV sales, service, commercial and recreational use, and all related economic activities - based on gross sales and administrative data. In 2005, ATV activities had an estimated economic impact of $\$ 2$ billion on the Canadian GDP (direct and indirect), and contributed over $\$ 89$ million to the GDP of Newfoundland and Labrador (Gunther, 2006).

Figures obtained from the Motorcycle \& Moped Industry Council and the Canadian OffHighway Vehicle Distributors Council $(2011 ; 2013)$ suggest the Canadian peak for new ATV retail sales was reached in 2003 with 92,778 new units sold nationally. Sales remained relatively stable before beginning to decline in 2008. Since 2011 new unit sales have stabilized, averaging over 51,000 units per year. In 2013, the estimated national retail value of new units of ATVs, parts, and accessories was \$764,569,104 (Motorcycle \& Moped Industry Council and the Canadian Off-Highway Vehicle Distributors Council, 2013).

However, retail sales of ATVs in the province of Newfoundland and Labrador appear to deviate from the national trend. Here, sales have remained relatively consistent between 2007-2013 at approximately 3,000 new units annually (Motorcycle \& Moped Industry Council and the Canadian Off-Highway Vehicle Distributors Council, 2013). The province has also gained traction in the overall proportion of units sold nation-wide, steadily increasing from $4.42 \%$ in 2009 to $7.05 \%$ in 2013.

It is well known that the purchase of an ATV is just the beginning of the expenditures related to owning and operating a recreational vehicle. All provinces require licensing in one form or another, and many trail systems nation-wide require permits or passes for their use. In addition to the basic purchase price of the vehicle, the after-market parts and accessories, repairs and maintenance costs, clothing and safety equipment, trucks, trailers, and insurance all factor into spending on ATV-related activities. Furthermore, additional expenditures such as food and accommodations consumed as part of ATV activities, gasoline to operate the ATV, and return travel to and from ATV trails quickly add up and make significant contributions to the local economy. 
In 2005, Canadians spent $\$ 3.3$ billion directly on activities involving 975,000 operating ATVs; of these 975,000 ATVs, approximately 66\% were used for recreational purposes (Gunther, 2006). The majority of the impacts of this spending came through induced expenditures. Induced expenditures reflect both the ratios of total to direct impacts and the multipliers for all iterations of derived from induced expenditures. Thus a direct GDP impact of \$928 million yields direct and indirect GDP of $\$ 1.4$ billion which, when multiplied through additional rounds of expenditures results in an induced GDP of $\$ 3.5$ to $\$ 5.5$ billion (Gunther, 2006). Just over one quarter of this was related to the purchase of new ATVs, and just under one quarter was related to accommodations and meals outside the home (Gunther, 2006). The third largest expenditure was for gasoline, which factored in not only the fuel for the ATV but for road travel to and from trail access points as well (truck and trailer).

In a 2012 Government of New Brunswick-commissioned survey, 77\% of respondents indicated that they planned to maintain or increase their level of ATV activity in the next five years. The same percentage indicated that they would increase their level of ATV activity if they had greater access to club or ATV federation trails. With average spending during same-day ATV tourism trips in New Brunswick reported by survey participants to be $\$ 91.75$, total ATV tourism visitor spending of $\$ 3.96$ million (including trail permit sales) generated a total sales volume of $\$ 7.2$ million, and the value added to the provincial economy from this visitor spending was estimated at \$2.5 million (Government of New Brunswick, 2012).

Coles' surveys of trail users in Haliburton County, ON in 2011 found that approximately $\$ 36,335,460$ is brought directly to the region through ATVs and ATV-related activities annually.

\section{Motorized Trails as Integrated Tourism Products}

There is a significant amount of research that shows how motorized trails have been successfully used as tourism products.

The repurposing of existing trails in West Virginia and in Ontario have created significant tourism assets in their regions. In both the Hatfield-McCoy, WV, and Haliburton County, ON, systems, the initial trails were developed around resource extraction, and when the industry declined the local economies suffered the same fate.

In the early 1990's, the Hatfield-McCoy area saw an economic revitalization with the development of an off-highway trail network that in part utilized existing trails and then built upon them (Nopper and Balenovich, 2011). As of 2013, the Hatfield-McCoy Trail System has grown to cover more than $1,100 \mathrm{~km}$ of off-road trails in seven of its nine project counties. All of the trails are open 365 days a year to ATVs, dirt bikes, and utility vehicles. The trails accommodate a range of skill levels, though the tourism literature suggests the trails can be challenging for first-time riders and recommends new visitors choose from a list of guided tour and ATV rental providers (thus creating a value added tourism product). In 2005, an economic 
assessment was conducted in West Virginia which determined that with the addition of the Hatfield-McCoy Trail Network, economic activity increased with an output of $\$ 8$ million. It also showed an income growth of $\$ 13$ million, which helped to generate 146 new jobs (Nopper and Balenovich, 2011).

Surveys conducted in 2011 in an attempt to identify the approximate annual economic benefits associated with ATV use in Haliburton County demonstrated that over $\$ 36$ million is spent per year by visiting ATV riders to the local area (Coles, 2011).

In the 2012 study commissioned by the Government of New Brunswick (using data from 20102011 ), it was found that trail permit holders spent an average of $\$ 51.88$ per person on same-day out-of-town ATV tourism trips, while trail permit holders' travel parties spent an average of $\$ 1,653$ on same-day out-of-town trips in New Brunswick annually. ATV tourism spending in New Brunswick was estimated to produce a total gross sales volume of $\$ 7.2$ million - which would sustain an estimated 54 full-time equivalent jobs. The study reported that ATV tourism in New Brunswick generated $\$ 908,316$ in taxes. More than half of that amount was collected by the federal government, the province collected just over $\$ 300,000$, and municipal governments received just over $\$ 50,000$ (mostly through business and property taxes).

Attracting tourist dollars is a very important factor for consideration when determining where and how to proceed with building and maintaining trail systems. In New Brunswick, significant differences existed between local and non-local trail users, with non-local trail users tending to have higher annual incomes. There is significant potential to develop a non-local tourism product that caters to the off-road vehicle market, with clear economic spinoffs for the local community and region as a whole. According to Dave Lee, President of the Eastman ATV Association in Manitoba, local communities adjacent to ATV trails are starting to see the benefits of the ATV as a tool for investment, money-making, and raising money for charities (Riderswest, 2013).

In Wisconsin, a case study focusing on the Cheese County Trail also suggested the economic impact of non-resident trail users is significant, with approximately two-thirds of all visitor days coming from users not living in the local region (Carper et al., 2012). Total spending of trail users exceeded \$15 million during the 12-month study period (November 2010-October 2011), and non-local trail user spending provided an economic stimulus that infused over $\$ 13$ million into the local economy, which supported approximately 190 local jobs and contributed almost $\$ 3$ million in employee compensation. Day trips accounted for nearly three quarters of the Cheese Country Trail usage (Carper, et al., 2012). Over 50\% of non-local motorized users of the Cheese Country Trail partook in dining activities while visiting the area, with a smaller (but still significant) number of users participating in shopping, visiting area attractions, and other local activities. For items such as food/drink, gas, and lodging, non-local trail users spent nearly twice as much as local residents (Carper, et al., 2012). 
A study conducted by the Margaret Chase Smith Policy Centre in 2005 demonstrated that generally, families with registered ATVs have higher incomes than the overall population in Maine. One quarter of households with registered ATVs have an income of $\$ 75,000$ or more, compared with $15 \%$ of households in the general population; out-of-state respondents reported higher incomes with $58.2 \%$ indicating household incomes of $\$ 75,000$ or more compared to $23.6 \%$ for households in Maine.

Elliot Lake in Ontario identifies itself as "one of the most exciting ATV adventure destinations in Canada", boasting the largest insured ATV trail network in Ontario (over $300 \mathrm{~km}$ ). According to the municipal website (City of Elliot Lake, 2014), the trails are carved through the "extraordinary landscape" of Northern Ontario, offering much more than an ATV ride - "An ATV adventure in Elliot Lake is an experience that will take riders past racing rivers, ancient rock escarpments, and transition forests". Supporting the thriving ATV tourism industry, Elliot Lake offers a wide variety of tourist amenities such as accommodations and food services to suit all tastes. There are also a number of local outfitters that have capitalized on the opportunities provided by the trail system, providing equipment and packages including guiding services.

The community-based ATV tourism model employed in Elliot Lake, ON, is focused on creating a stimulus for economic development with an emphasis on tourism. While they acknowledge and support local trail users, the primary goal of developing the ATV asset was to reap the economic benefits of attracting new visitors and new money. The main task for the community was to secure cooperation from everyone in building a trail system that placed a direct emphasis on the tourism experience, while at the same time maximizing local recreational opportunities (Suthey Holler Associates, 2003). The clear goal was to attract new people and new money into the Town.

Unfortunately, motorized trails sometimes create conflict. During the development of the City of Kawartha Lakes Trails Master Plan in 2006, addressing ATV usage in urban areas was a recurring topic. A number of trail users and members of the general public expressed concern regarding the use of ATVs and dirt bikes sharing the trail with pedestrian users. This was met with concern from motorized trail users and local business interests who noted the expected negative impacts to the local economy if this highly profitable trail use was limited or removed. Both the Fenelon Falls and Lindsay Chambers of Commerce communicated the economic importance of allowing ATV and snowmobile access to local business areas. They, along with a number of other trails users, noted the potential economic benefits of motorized tourism efforts and trail-related spinoffs (City of Kawartha Lakes, 2006). There was some support for ATV and snowmobile bypasses around urban areas, but these were seen as long-term measures.

According to Norman (2010), significant differences exist between trail uses in urban areas compared to rural regions of Canada. Urban trails are most often associated with non-motorized use. Given the typically large number of pedestrians and cyclists using these trails, it is often not 
desirable to permit motorized vehicle use. With the vast majority of trails (95\%) located in rural regions, people living in urban centres most often must travel to rural regions to find diversity in their trail experiences (Norman, 2010). In Newfoundland and Labrador, only $208 \mathrm{~km}$ of managed trail are considered urban versus the $7,232 \mathrm{~km}$ considered rural.

The Town of Conception Bay South faced a very similar scenario during the development of its T'Railway Development Plan in 2010 and has chosen to respond by pursuing a long-term solution of constructing an ATV Bypass Route. The Town prides itself of having character that has important elements of urban and rural living. The ATV Bypass Route and its ability to connect into the pan-provincial multi-use T'Railway Provincial Park gives it an important strategic advantage. Conception Bay South will provide a gateway between the densely populated urban St. John's region to the east and the more rural municipalities and wilderness to the west via the T'Railway.

The additional costs incurred from motorized use trails are expected to be offset by a permit structure or user-pay/trail pass system, which forms part of the economic benefits derived from an ATV trail. This helps recover costs involved in creating, maintaining, and operating the trail, and helps offset the costs of product development and management (Suthey Holler Associates, 2003). Tourists will be expected to pay for a trail pass to access the trail system, similar in principle to that of a ski resort where users pay to use the slopes and avail of the infrastructure associated with the enterprise. In this model, local recreational users are not expected to purchase trail passes, but are required to be local residents and be members of the local ATV club (Suthey Holler Associates, 2003). At its Annual General Meeting in 2009, the New Brunswick ATV Federation passed a motion to introduce the use of trail passes for all motorized vehicle drivers using the provincial trail system. The membership felt that the use of trail passes will be an effective way to manage the trail system, and it will help the federation to have better control of the system (LeBlanc, 2009).

\section{The case for an ATV Bypass Route around Conception Bay South}

In 2009, the Provincial Government of Newfoundland and Labrador launched its new vision for the future of tourism in the province. Vision 2020 provided a plan for extraordinary growth, addressing real and perceived barriers facing the industry. It set an ambitious target to double the annual tourism revenue in Newfoundland and Labrador by 2020 (Government of Newfoundland and Labrador, 2009).

In 2014, the number of non-resident automobile, air, and cruise visitors travelling to the province reached an estimated 487,407 visitors for the period ending November 2014, an increase of $2.0 \%$ over 2013 (Government of Newfoundland and Labrador, 2014). These non-resident visitors are arriving (and spending) in high numbers and the Province, via its regional Destination Management Organizations, is working in earnest to ensure high-quality tourism experiences are readily available to meet their needs. 
Product development has focused on developing and providing experiences, services, and infrastructure that exceed customer expectations, with particular emphasis on the following:

- Protecting the natural environment and culture;

- Strengthening and building on tourism demand influencers;

- A focus on shoulder and winter seasons;

- Strengthening and building on destination areas;

- Strengthening touring corridors and community hubs;

- Filling gaps;

- Generally upgrading and enhancing the market readiness of tourism products and services;

- Improving traveller services and transportation infrastructure, most particularly ferry services and highway signage; and

- Strengthening the industry and government organizations (Government of Newfoundland and Labrador, 2016).

The Town of Conception Bay South holds membership in both the Destination St. John's and Legendary Coasts Destination Management Organizations, as its geographic location holds definite advantages that cater to both the urban and rural visitor experience respectively. The Town is also a member of Hospitality Newfoundland and Labrador, a non-profit membership association that leads, supports, represents and enhances the province's tourism industry (Hospitality Newfoundland and Labrador, 2014).

The Hatfield-McCoy and Haliburton case studies described above are very intriguing from the Town's perspective due to their close proximity to highly populated areas within a day's drive. The neighbouring urban centres lack motorized use trails, making them a perfect day-trip starting point for visitors to the metro areas. The close proximity of Conception Bay South to the provincial capital (approximately $25 \mathrm{~km}$ ) makes it an ideal location for day trips from the City of St. John's. Optimizing these opportunities was one of the findings in the 2002 Tourism Infrastructure Master Plan. Visitors attracted to the metro region can take advantage of regional tourism and recreational assets, and the potential to develop additional shopping, dining, and accommodations, as well as ATV rental and servicing enterprises is significant.

The ATV Bypass Route will add yet another tourism asset to the growing provincial inventory, as well as that of the Northeast Avalon itself. It is an excellent fit with the provincial vision and can be readily marketed and promoted through existing tourism channels to markets ranging from interprovincial to international. There is significant potential for tourism operators to create packages based around ATV tourism by bundling local services and amenities that will offer visitors a comprehensive regional flavour. For existing operators, depending on their niche, the addition of a four season attraction such as the ATV Bypass Route could help offset downtime outside the typically busy summer period. 
In Conception Bay South, as in other jurisdictions, the motorized trail will not be stand-alone but will be developed into an experience where an ATV ride can be combined with other tourism experiences in the Town and region. Sustainability over time is the ultimate goal. The experience provided by this route will not be the impetus for development but will certainly capitalize on local culture, heritage, and the natural features of the environment (Suthey Holler Associates, 2003).

The option for out-of-province riders to access eastern Newfoundland via the Marine Atlantic ferry terminal in Argentia can significantly decrease road travel distance to access the eastern ATV-friendly trails. Tourists have the option to make a round-trip via this entry point or may choose to access the terminal in Port aux Basques if they have more time. The ATV Bypass Route and its connection to the T'Railway Provincial Park can become an excellent marketing point for Marine Atlantic, as it will encourage additional vehicular and trailer traffic.

Throughout this research, it was found that many trails that allow motorized use are in fact shared-use trails, which brings about its own set of challenges. The past several decades have seen significant efforts to convert former rail beds into a system of recreational trails across North America; the decommissioned rail bed in Newfoundland and Labrador being no exception. While the majority of former rail bed trails cater to non-motorized users, there is a growing interest in trails, use areas, and open spaces that cater to motorized users (Carper et al, 2012). As previously noted, the vast majority of the Newfoundland T'Railway is designated as multi-use, permitting both non-motorized and motorized use. However, in certain communities on the Northeast Avalon Peninsula, namely the City of St. John's, the City of Mount Pearl, and the Town of Conception Bay South, this corridor has been designated exclusively for pedestrian (non-motorized) use. This has left a significant gap for motorized trail users to ride legally in the immediate local area, which has led to a renewed call to move forward with plans to establish an ATV Bypass Route around Conception Bay South, thus providing an avenue for participation in ATV activities in close proximity to urban areas.

\section{Conclusion}

In addition to the obvious economic benefits, trails can offer an abundance of opportunities for volunteering in the community and increased ownership of the asset. Among the many benefits are clean-up initiatives, informal monitoring of trail activity and conditions, and involvement in trail education and community event planning (Lake, 2013). Partnerships among community groups, businesses, property owners, municipal and provincial governments, and residents can be solidified through a trail where collective pride and ownership prevails. Regular trail-based recreation and special events, such as Trail Days, engage people of all income brackets, all age groups and all cultures, thus helping build a stronger sense of community. Partnerships between municipalities and user groups are welcome and necessary. In the City of Kawartha Lakes for 
example, a number of organizations with substantial membership bases expressed interest in partnering with the City in mapping and trails planning, as well as ongoing maintenance efforts.

While tourism in other Atlantic provinces is stable, strong increases in non-resident visitation and spending are evident in Newfoundland and Labrador. The local sector offers a wide variety of tourism experiences in natural areas, cultural attractions and outdoor adventures.

Newfoundland and Labrador as a tourism destination along with individual destinations within the province are receiving high profile attention nationally and internationally (Nalcor Energy, 2012).

The Town of Conception Bay South has made the development and marketing of its tourism assets a priority, and the creation of the ATV Bypass Route is an important component of future growth in this important economic sector. Numerous studies and surveys have demonstrated that integrated, high quality trail infrastructure entices non-local riders, who avail not only of the trail but complementary services and amenities within the region. There is tremendous potential in the Town to build on existing infrastructure that will support tourism, which over time is expected to grow from existing basic amenities to a wide-range of products and services that cater to the motorized vehicle market.

\section{Author biography}

Krista has worked with the Town of Conception Bay South as an Economic Development Coordinator since 2014, and is currently pursuing a certificate in Economic Development from the University of Waterloo. She grew up in a tiny rural community on the island of Newfoundland's Northern Peninsula, and in 2001 obtained a degree in Environmental Studies from Memorial University. She spent several years working with non-profit organizations, which gave her a genuine appreciation for community development. In her current role, she works to cultivate and expand relationships with businesses and community-based organizations to help foster growth and development in Conception Bay South.

\section{References}

Carper, C., Guth, J., Kakde, E., Marcouiller, D., Ohlrogge, P., and Wolfe, L. (2102). Motorized Outdoor Recreation and Tourism development within Trailside Communities: A Case Study of Cheese Country Trail Users and Economic Impacts in Southwestern Wisconsin. University of Wisconsin. Retrieved from http://headwaterseconomics.org/wphw/wpcontent/uploads/Trail_Study_99-WI-Motorized-Rec-Trailside-Communities.pdf

City of Elliot Lake (2014). ATV Elliot Lake! Retrieved from http://www.cityofelliotlake.com/en/visit/atv.asp. 
City of Kawartha Lakes (2006). Trails Master Plan. Retrieved from

http://www.city.kawarthalakes.on.ca/residents/parks-recreation-culture/parks-and-trails/city-ofkawartha-lakes-trails-master-plan.

Coles, C. (2011). Economic Benefits Assessment of ATV Riding Activities in Haliburton County. Retrieved from

http://www.highlandseast.ca/files/Economic\%20Benefits \%20Assessment\%20of\%20ATV\%20Ri ding\%20Activities\%20in\%20Haliburton\%20County.pdf.

Englin, J. and Holmes, T. (2005). Benefits and Costs of Resource Policies Affecting Public and Private Land: Papers from the Annual Meeting, Salt Lake City, Utah, February 14-15, 2005. Retrieved from http://www.americantrails.org/resources/motors/usefeeohvrec05.html.

Englin, J., Holmes, T. and Niell, R. (2006). Alternative Models of Recreational Off-Highway Vehicle Site Demand. Retrieved from http://link.springer.com/article/10.1007\%2Fs10640-0069017-z\#page-2.

Government of New Brunswick (2012). The Economic Impact of ATV Tourism in New Brunswick by NBATVF Trail Permit Holders. Retrieved from http://nbatving.com/data/961nbatvf_touris meconomicimpactreport2011.pdf.

Government of Newfoundland and Labrador (2013). 2011 Provincial Visitor Exit Survey. Retrieved from http:/www.tcr.gov.nl.ca/tcr/publications/Visitor\%20Exit\%20Survey/2011_Visitor_Exit_Survey _Highlights_Document_Final TCR Revised.pdf.

Government of Newfoundland and Labrador (2014). Tourism Highlights, November 2014. Retrieved from http://www.tcr.gov.nl.ca/tcr/publications/2014/Tourism_performance_2014_YTD_November_2 014.pdf.

Government of Newfoundland and Labrador (2016). Tourism Product Development. Retrieved from http://www.btcrd.gov.nl.ca/Tourism/tourism_development/index.html.

Government of Newfoundland and Labrador (2009). Uncommon Potential: A Vision for Newfoundland and Labrador Tourism. Retrieved from http://www.tcr.gov.nl.ca/tcr/publications/2009/Vision_2020.pdf.

Gunther, P. (2006). The Economic Impact of All Terrain Vehicle Recreation in Canada: National, Provincial, and Territorial. Retrieved from http //www.cohv.ca/impact.pdf.

Hatfield-McCoy Trails (2014). Hatfield-McCoy Trails Is... Retrieved from http://www.trailsheaven.com/About-the-TRAILS/Hatfield-McCoy-Trails-Is.aspx. 
Hospitality Newfoundland and Labrador (2014). About HNL. Retrieved from http://hnl.ca/abouthospitality-newfoundland-and-labrador/.

Lake, J. (2013). Socio-Economic Benefits of Trail Development in Conception Bay South. Retrieved from http:/pced.uwaterloo.ca/index.php/pced/article/view/55/52.

LeBlanc, J. (2009). Trail Passes Now in Use on NB ATV Trails. Retrieved from http:/nbatving.com/data/160-2888675tj1.pdf.

Margaret Chase Smith Policy Centre (2005). Economic Contributions of ATV-Related Activities in Maine. Retrieved from http://www.nohvcc.org/docs/economicimpacts/Economic_Contributions_of_ATV_Related_Activities_in_Maine.pdf? sfvrs n $=0$.

Motorcycle \& Moped Industry Council and the Canadian Off-Highway Vehicle Distributors Council (2011). Motorcycle, Scooter, \& All-Terrain Vehicle Annual Industry Statistics Report. Retrieved from

http://www.mmic.ca/images/content/PDF/Annual\%20Industry\%20Report\%20MMIC\%20\&\%20 COHV\%20-\%202011\%20-\%20summary.pdf.

Motorcycle \& Moped Industry Council and the Canadian Off-Highway Vehicle Distributors Council (2013). Motorcycle, Scooter, \& All-Terrain Vehicle Annual Industry Statistics Report. Retrieved from http:/www.mmic.ca/images/content/PDF/Annual\%20Ind ustry\%20Report\%20MMIC\%20\&\%20 COHV\%20-\%202013\%20-\%20summary.pdf.

Nalcor Energy (2012). Labrador-Island Transmission Link Environmental Impact Statement

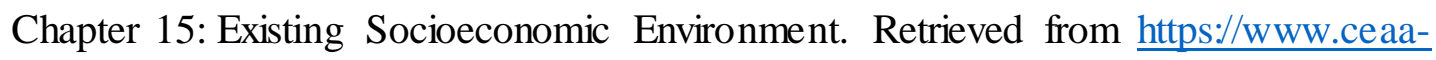
acee.gc.ca/050/documents/55076/55076E.pdf.

Newfoundland T'Railway Council (2014). About the NewfoundlandT'Railway. Retrieved from http://www.trailway.ca/about.php

Nopper, P. and Balenovich, C. (2011). Feasibility Management Study of Off-Road Vehicle Trails in Highlands East, Haliburton County Ontario. Retrieved from http:/www. highlandseast.ca/files/Feasibility $\% 20$ of $\% 200$ ff $\% 20$ Road $\% 20$ Trails $\% 20 \mathrm{in} \% 20 \mathrm{Highl}$ ands $\% 20$ East $\% 20$ by $\% 20 \mathrm{Paul} \% 20$ Nopper\%20and $\% 20 \mathrm{Chris} \% 20 \mathrm{Balenovich} . \mathrm{pdf}$.

Norman, T. (2010). Canadian Trails Study: A Comprehensive Analysis of Managed Trails and Trail Uses. Retrieved from http//www.ntc-canada.ca/pdf/NTC-Canadian-Trails-Study.pdf.

PricewaterhouseCooper LLP (2004). Economic Impact Analysis Trans Canada Trail in Ontario. Retrieved from http:/atfiles.org/files/pdf/TransCanadaEcon.pdf. 
Riderswest (2013). Manitoba ATV Clubs Gain Ground During 2013 Season. Retrieved from http://www.riderswestmag.com/atvzone/article/manitoba_atv_clubs_gain_ground_during_2013 season.

Suthey Holler Associates (2003). A Development Manual for a Community-Based ATV Tourism Product. Retrieved from http://atvontario.com/pdf/ATV\%20manual.pdf.

Tourism Elliot Lake (2014). Retrieved from

http://www.tourismelliotlake.com/en/explore/atv.asp.

Tract Consulting Inc. (2007). Conception Bay South T'Railway Study. Retrieved from http://www.conceptionbaysouth.ca/wp-content/uploads/2012/01/CBS_TRailWay_Study.pdf.

Tract Consulting Inc. (2011). Town of Conception Bay South T'Railway Development Plan. Town of Conception Bay South (2002). Tourism Infrastructure Master Plan. 